\title{
Redescription of the monotypic genus Scelidomacbus Pocock, 1899 (Aranei: Palpimanidae) and its type species
}

\author{
Переописание монотипического рода Scelidomacbus Pocock, 1899 \\ (Aranei: Palpimanidae) и его типового вида
}

\author{
Sergei L. Zonstein ${ }^{1}$, Yuri M. Marusilk ${ }^{2,3,4}$, Mikhail M. Omelko,

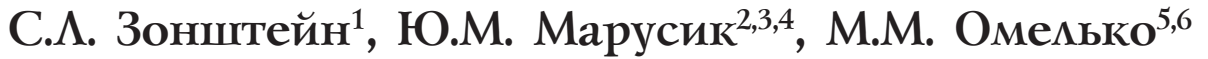

\footnotetext{
${ }^{1}$ Steinhardt Museum of Natural History, Tel-Aviv University, 69978 Tel-Aviv, Israel. E-mail: znn@post.tau.ac.il

${ }^{2}$ Institute for Biological Problems of the North RAS, Portovaya Str. 18, Magadan 685000 Russia.

${ }^{3}$ Department of Zoology \& Entomology, University of the Free State, Bloemfontein 9300, South Africa.

${ }^{4}$ Zoological Museum, University of Turku, FI-20014 Turku Finland.

${ }^{5}$ Far Eastern Federal University, Sukhanova 8, Vladivostok 690950, Russia.

${ }^{6}$ Federal Scientific Center of the East Asia Terrestrial Biodiversity FEB RAS, Vladivostok 690022 Russia.

${ }^{2}$ Институт биологических проблем Севера ДВО РАН, ул. Портовая 18, Магадан 685000 Россия.

${ }^{5}$ Дальневосточный Федеральный университет, ул. Суханова 8, Владивосток 690950 Россия.

${ }^{6}$ ФНЦ биоразнообразия наземной биоты Восточной Азии ДВО РАН, Владивосток 690022 Россия.
}

KEY WORDS: Araneae, Chediminae, Socotra, holotype.

КЛЮЧЕВЫЕ СЛОВА: Araneae, Chediminae, Сокотра, голотип.

ABSTRACT. Scelidomachus socotranus Pocock, 1899, the type species of Scelidomachus Pocock, 1899 is redescribed based on the holotype and paratype males from Socotra. The genus is rediagnozed.

How to cite this article: Zonstein S.L., Marusik Yu.M., Omelko M.M. 2018. Redescription of the monotypic genus Scelidomachus Pocock, 1899 (Aranei: Palpimanidae) and its type species // Arthropoda Selecta. Vol.27. No.1. P.53-56. doi: 10.15298/arthsel. 27.1 .07

РЕЗЮМЕ. Scelidomachus socotranus Pocock, 1899, типовой вид рода Scelidomachus Pocock, 1899 переописан на основании голотипа и паратипа из Сокотры. Приведён новый диагноз рода.

\section{Introduction}

The Palpimanidae is a relatively small family with 144 species assigned to 18 genera [WSC, 2018]. Palpimanids are a rather poorly studied group of spiders, with only a few recently published revisions dealing largely with Neotropical genera [e.g. see Piacentini et al., 2013; Castro et al., 2015]. Most of the Old World species were described in the 19th century or the first half of the 20th century. Four genera, all from the Old World, are monotypic: Badia Roewer, 1961, Chedima Simon, 1873, Hybosidella Zonstein et Marusik, 2017 and Scelidomachus Pocock, 1899. The type species of the Chedima was redescribed only recently [Zonstein, Marusik, 2017b]. Figures of the copulatory organs are missing for Badia, a genus known from the original description and restricted to Senegal, seems misplaced in the family [Platnick, 2015]; Scelidomachus is known only from Socotra. Pocock described the latter genus and its only species, S. socotranus Pocock, 1899, based on two males, without any figures. The genus was placed in Simon's [1893] family-group taxon 'Chedimeae' (Chediminae), being diagnosed and distinguished from related genera exclusively by the eye pattern. Four years later Pocock [1903] repeated (verbatim) his description of both the genus and the species and provided a sketchy text figure (lacking a number) of the palp, and an additional figure of the eyes. A habitus figure of $S$. socotranus was also recently provided by Zonstein \& Marusik [2013] to demonstrate the differences among the chedimine genera.

While seeking to revise the Old World Palpimanidae, we recently had an opportunity to examine the holotype and paratype of $S$. socotranus kept in the Natural History Museum, London (NHML). The aim of this paper is to provide a detailed diagnosis of Scelidomachus relative to other chedimine genera, and a redescription of the somatic characters and palp of $S$. socotranus.

\section{Material and methods}

Photographs were taken using an Olympus SZX16 stereomicroscope with an Olympus E-520 camera, and prepared using the CombineZP software in the Zoological Museum of the University of Turku. Lengths of leg and palp segments are given in the following sequence: total (femur, patella, tibia, metatarsus, tarsus). All mea- 

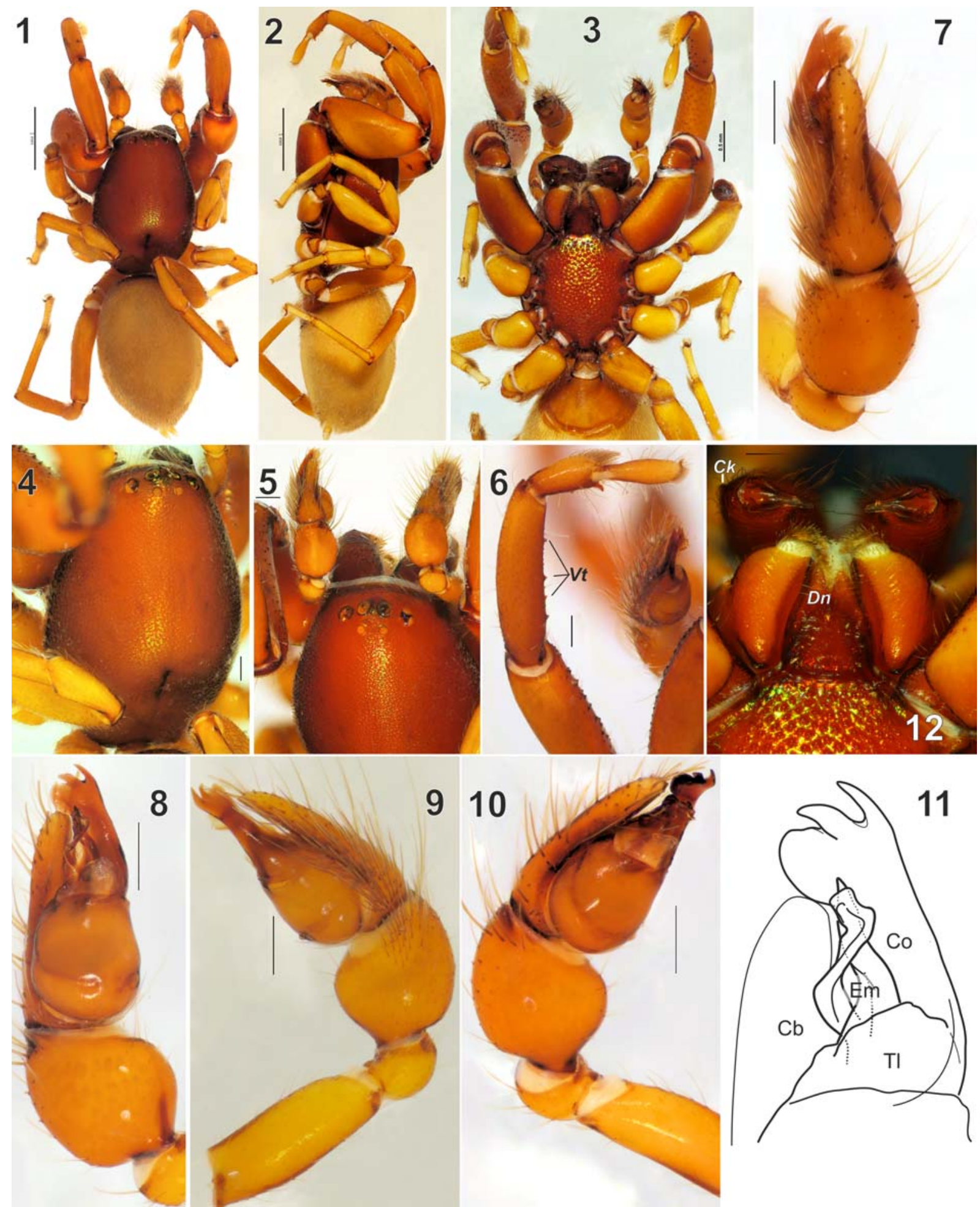

Figs 1-12. Scelidomachus socotranus, paratype male. 1-2 - habitus, dorsal and lateral views; $3-4$ - prosoma, ventral and subdorsal views; 5 - anterior part of carapace, showing eyes; 6 - leg I and palp, ventro-retrolateral view; 7-8 - palpal tibia, cymbium and bulb, dorsal and ventral views; 9-10 - entire palp, retrolateral and ventro-prolateral views; 11 - distal portion of bulb, showing embolus and conductor, ventral view; 12 - mouth parts, ventral. Scale bars $=0.2 \mathrm{~mm}$ if not otherwise indicated. Abbreviations: $\mathrm{Cb}-\mathrm{cymbium} ; \mathrm{Ck}-$ keel of chelicera; $C o$ - conductor; $D n$ - labial deep notch; Em - embolus; $T l$ - tegular lamella; $V t$ - ventral thorns.

Рис. 1-12. Соматические признаки Scelidomachus socotranus, паратип: 1-2 - габитус, сверху и сбоку; 3-4 - головогрудь, снизу и полусверху; 5 - передняя часть каракса, показыны глаза; 6 - нога I и пальпа, снизу-ретролатерально; 7-8 - пальпа (голень-лапка), сверху и снизу; 9-10 - вся пальпа, ретролатерально и вентро-пролатерально; 11 - вершинная часть бульбуса с 
surements are given in millimeters. For eyes and spinnerets, the abbreviations are the standard for Aranei. The names of the localities are specified and the coordinates are given according to Bezdik et al. [2012].

\section{Taxonomy}

\section{Subfamily Chediminae Simon, 1893}

Chedimeae Simon, 1893: 402.

Chediminae: Platnick, 1975: 2; Zonstein, Marusik, 2013: 36.

COMMENTS. Twelve genera are currently considered in Chediminae: Badia, Boagrius Simon, 1893, Chedima, Chedimanops Zonstein et Marusik, 2017, Diaphorocellus Simon, 1893, Hybosida Simon, 1898, Hybosidella, Levymanus, Sarascelis Simon, 1887, Scelidocteus Simon, 1907, Scelidomachus and Steriphopus Simon, 1887. Differences between them were briefly discussed by Zonstein \& Marusik [2013] in support of placement of the newly described Levymanus from Israel. Most chedimine genera and species are restricted to the African continent and adjacent Madagascar, the Seychelles and the Middle East. Only two genera, Boagrius and Steriphopus, occur exclusively in South-East Asia (we consider the East-African members of the former genus as not actually belonging to Boagrius; in our opinion they may belong to a new genus, as yet undescribed), whereas Sarascelis is distributed in both tropical Africa and South Asia [see Zonstein and Marusik 2013, fig. 51].

\section{Scelidomachus Pocock, 1899}

Scelidomachus Pocock, 1899: 151; 1903: 194.

TYPE SPECIES. Scelidomachus socotranus Pocock, 1899 , by monotypy.

DIAGNOSIS. The structure of the palpal organ in Scelidomachus resembles that in Hybosidella: both these genera differ from all other chedimine palpimanids in having the apically dilated and flattened conductor. Scelidomachus can be easily distinguished from Hybosidella by a number of eyes ( $8 v s .2$ ), as well as by shape of the conductor, which is tridentate in the former, but bifurcate in the latter taxon (Figs 7-11; cf. Zonstein \& Marusik, 2017a, figs 53, 54, 6466).

GENERIC CHARACTERS. Based entirely on the characters of $S$. socotranus (see below).

SPECIES INCLUDED. Only the type species.

\section{Scelidomachus socotranus Pocock, 1899} Figs 1-12.

Scelidomachus socotranus Pocock, 1899: 41 ( $\left.\sigma^{7}\right)$; Pocock, 1903: 194, pl. 26, f. 3 ( $\left.\sigma^{7}\right)$; Zonstein, Marusik, 2013: 32, f. 7 ( $\left.\sigma^{7}\right)$

TYPE MATERIAL: YEMEN: holotype $\sigma^{7}$, Socotra Island, Dahamis, $12^{\circ} 37^{\prime} \mathrm{N}, 54^{\circ} 07^{\prime} \mathrm{E}$, ca. $120-150 \mathrm{~m}$, December 1898 , W.R.O. Grant (NHML). Paratype: $1 \sigma^{7}$, Socotra Island, Thluteen (= JenaAgahan), $12^{\circ} 34^{\prime} \mathrm{N}, 54^{\circ} 04^{\prime} \mathrm{E}-12^{\circ} 36^{\prime} \mathrm{N}, 5^{\circ} 05^{\prime} \mathrm{E}, 400-800 \mathrm{~m}$, December 1898, W.R.O. Grant (NHML).

NOTE. The preserved condition on the paratype is better than that of the holotype, hence the redescription below is based on the former specimen.

DIAGNOSIS. See diagnosis for the genus (above).
REDESCRIPTION. Male (paratype). Body length 6.10 . Colour in alcohol: carapace and chelicerae dark carmine; labium, sternum, palps and legs yellowish-red; abdomen uniformly light yellowish-brown. General appearance as in Figs 1-5. Carapace 2.39 long, 1.71 wide, with fine-corrugated cuticle, oval in dorsal view. Cephalic part not raised behind eye area. Thoracic fovea short, deep and longitudinal (Figs 1, 4). Eye sizes and interdistances: AME 0.14, ALE 0.10, PLE 0.08, PME 0.06, AME-AME 0.05, AME-ALE 0.08, AME-PLE 0.09, ALE-PLE <0.01, PLE-PME 0.16, PME-PME 0.12. Clypeus about two times higher than AME diameter. Chilum inconspicuous. Chelicerae retrolaterally with longitudinal low and flattened lateral keel and stridulatory ridges; cheliceral furrow with few peg teeth; lateral sides close to fang with small keel (Ck, Fig. 12). Sternum shield-like with granulate texture; labium about 1.5 times as long as broad at base and deeply notched anteriorly ( $D n$, Fig. 12). Legs: Leg formula: 1,4,2,3. Leg I: Coxa very large (Figs 2-3), dorsally with numerous tiny thorns; femur thick and swollen; femur, patella and tibia ventrally with numerous small cuticular thorns, metatarsus with few large ventral thorns (distal-most of them largest); tibia and metatarsus with well-developed prolateral scopula. Legs II-IV long and slender. Legs and palp length: palp $1.86(0.62,0.21,0.48,-$, $0.55)$; I $5.57(1.77,1.56,1.28,0.47,0.49)$; II 4.35 (1.32, $0.88,0.90,0.77,0.48)$; III $3.76(1.14,0.70,0.64,0.80$, $0.48)$; IV 5.60 (1.62, 0.91, 1.31, 1.24, 0.52).

Leg tarsi scopulate; claw tufts well-developed. Paired tarsal claws very narrow with 1-2 tiny subapical teeth. Paired claws on tarsus I noticeably smaller than those on tarsi IIIV. Abdominal scutum forming a rather short pedicel tube (Fig. 3); dorsal portion of scutum relatively small. Spinnerets not encircled by sclerotized ring; AMS small, cylindrical, two-segmented; PMS and PLS absent at least in males. Palp (Figs 6-11): femur short, length subequal to length of cymbium; patella small without dorsal process, subglobular; tibia strongly swollen, as long as wide, $1.75 \mathrm{x}$ wider than femur. Cymbium long and thin, tapering distally. Tibia and base of cymbium with retrolateral brush of more dense setae. Bulb longer than cymbium due to very long "conductor" $(\mathrm{Co})$; tegulum longer than wide and wider than diameter of femur; prolateral part with large lamella $(T l)$ hiding base of embolus; "conductor" as long as tegulum, expanded at its tip with tridentate distal margin; embolus $(E m)$ wide, flat, partly membranous, twisted in apical half; tip of embolus coincides with tip of cymbium.

DISTRIBUTION. The species is known only from Socotra, Yemen.

Acknowledgements. We thank Janet Beccaloni, the curator of the Natural History Museum, London, for access to the type specimens and Seppo Koponen (University of Turku) for providing museum facilities. Naomi Paz (Tel-Aviv University) kindly checked the English in an earlier draft. We are also grateful to Martín Ramírez whose comments allow to improve this paper. This study was supported in part by the Ministry of Absorption, Israel and by the Far Eastern Federal University (Vladivostok).

эмболюсом и кондуктором, снизу; 12 - ротовой аппарат, снизу. Масштаб = 0,2 мм если не указано иначе. Сокращения: $C b-$ цимбиум; $C k$ - киль хелицеры; $C o-$ кондуктор; $D n-$ глубокая вырезка нижней губы; $E m-$ эмболюс; $T l-$ тегулярная пластинка; $V t$ - вентральные шипики. 


\section{References}

Bezdik J., Purchart L., Král K., Hula V. 2012. List of local Socotran geographical names used in entomological literature // Hájek J., Bezdik J. (eds.). Insect biodiversity of the Socotra Archipelago. Acta Entomologica Musei Nationalis Pragae. Vol.52. Suppl.2. P.27-67.

Castro D., Baptista R., Grismado C., Ramírez M. 2015. New species and records of Otiothopinae from the Southern Atlantic Rainforest, with notes on the claw tufts in Fernandezina Birabén (Araneae: Palpimanidae) // Zootaxa. Vol.4012. No.3. P.465-478.

Piacentini L.N., Ávila C.S.L., Pérez M.E., Grismado C.J. 2013 The first palpimanid spiders from Bolivia: two new species of the genus Otiothops MacLeay, and the female of Fernandezina pulchra Birabén (Araneae: Palpimanidae: Otiothopinae) // Zootaxa. Vol.3619. P.491-500.

Platnick N.I. 2015. The world spider catalog, version 15.0. American Museum of Natural History, Available from: http:// research.amnh.org/iz/spiders/catalog (Accessed 12 January 2018).
Pocock R.I. 1899. The Expedition to Socotra. VII. Descriptions of one new genus and four new species of spiders // Bulletin of the Liverpool Museums. Vol.2. No.2. P.40-42.

Pocock R.I. 1903. Arachnida // Forbes H.O. (ed.). The Natural History of Sokotra and Abd-el-Kuri. Liverpool. P.175-208

Simon E. 1893. Histoire naturelle das araignées. Paris. Vol.1. P.257488.

WSC 2018. World Spider Catalog. Natural History Museum Bern, online at http://wsc.nmbe.ch, version 19.0. (Accessed 18 January, 2018).

Zonstein S., Marusik Yu.M. 2013. On Levymanus, a remarkable new spider genus from Israel, with notes on the Chediminae (Araneae, Palpimanidae) // ZooKeys. Vol.326. P.27-45.

Zonstein S.L., Marusik Yu.M. 2017a. Descriptions of the two-eyed African spider genera Chedimanops gen. n. and Hybosidella gen. n. (Araneae, Palpimanidae, Chediminae) // African Invertebrates. Vol. 58. No.1. P.23-47.

Zonstein S.L., Marusik Yu.M. 2017b. A redescription of Chedima purpurea Simon, 1873, with notes on the unique copulative stopper mechanism in females (Aranei: Palpimanidae) // Arthropoda Selecta. Vol.26. No.3. P.225-232.

Responsible editor K.G. Mikhailov 